\title{
ASSESSING THE UNIVERSITY STUDENTS' ENTREPRENEURIAL INTENTION: ENTREPRENEURIAL EDUCATION AND CREATIVITY
} Ari Saptono $^{1}$, Dedi Purwana ${ }^{2}$, Agus Wibowo ${ }^{3}$, Setyo Ferry Wibowo ${ }^{4}$, Saparuddin Mukhtar ${ }^{5}$, Heri Yanto ${ }^{6}$, Sugeng Hadi Utomo ${ }^{7}$, Djoko Dwi Kusumajanto ${ }^{8}$

${ }^{1,2,3,4,5}$ Faculty of Economics, Universitas Negeri Jakarta, Indonesia, ${ }^{6}$ Faculty of Economics, Universitas Negeri Semarang, Indonesia, ${ }^{7,8}$ Faculty of Economics, Universitas Negeri Malang, Indonesia

Email: agus-wibowo@unj.ac.id Article History: Received on $18^{\text {th }}$ February 2019, Revised on $17^{\text {th }}$ April 2019, Published on $25^{\text {th }}$ August 2019

\begin{abstract}
Purpose of the study: This study examines the impact of creativity and entrepreneurship education on student entrepreneurial intentions at Jakarta State University.

Methodology: This study, we applied quantitative research which conducting in two-phase First, we perform exploratory factor analysis test, and the second phase, we confirmatory factor analysis using AMOS version 18.

Main Findings: This study carried out the findings that there is an impact on creativity on entrepreneurial education, lectures on individual creativity, entrepreneurial education on entrepreneurial intention, and creativity supported in the university on individual creativity. Furthermore, creativity supported not impact on entrepreneurial intention, and individual creativity has not to impact on entrepreneurial intention.
\end{abstract}

Applications of this study: This research can be used by university leaders to increase students' intention to become entrepreneurs through optimizing entrepreneurship education and creativity support from universities.

Novelty/Originality of this study: In this study, we found that there was an influence of lecturer on creativity on entrepreneurship education. Previous researchers have never revealed this finding. Our research also found the impact of individual creativity on the intention of entrepreneurship. This finding has not been revealed in some previous studies.

Keywords: Creativity supported in the university, Individual creativity, Lectures' creativity, Entrepreneurial education, Entrepreneurial intention.

\section{INTRODUCTION}

Entrepreneurship has become a popular and urgent study topic of researchers in both developed and developing countries. Entrepreneurial characteristic like job creation, innovativeness, and creativity, high employment, positive social development as well as economic growth (Acs \& Audretsch, 2018; Rowley, Baregheh, \& Sambrook, 2011; Purwana, 2017; and Shane \& Venkataraman, 2000). Several studies concluded that the more entrepreneurs in a country, the prosperity of the people would be quickly achieved (Obschonka, 2010 and Lee, 2011).

Indonesia, as a developing country with the fourth largest population in the world, also increases the number of entrepreneurs intensively. However, data from the Global Entrepreneurship Index (GEI), states that Indonesia is ranked $94^{\text {th }}$ out of a total of 137 countries surveyed (Ács, Szerb, \& Autio, 2018). In the Southeast Asia region, Indonesia's position is far below Malaysia (58), Brunei Darussalam (53) and Singapore (27). The GEI data means that there are not many entrepreneurs in Indonesia. Therefore, one of the Indonesian government is the optimization of entrepreneurship education from primary school to university. Facts in Indonesia, universities have empowered entrepreneurship education to increase the number of entrepreneurs (Puspayoga, 2017 \& Purwana, 2017).

According to Puspayoga, the Indonesian government through the Ministry of Research and Technology (Kemenristekdikti) has instructed entrepreneurship training programs on campuses, ranging from entrepreneurship capacity-building materials to entrepreneurship training through national entrepreneurial movement for students, farmers, and strategic groups. One of the government's essential programs in universities in the Development of Student Entrepreneur Program (PMW). Entrepreneurship program initiated by higher education (Dikti) through the Directorate of Directorate General of Higher Education since July 2009. This program provides capital for students who have a business or business plans.

Universitas Negeri Jakarta (UNJ) has provided support and conducive climate for the birth of entrepreneurship among the students. Many programs are implemented to ensure knowledge and skills to attract entrepreneurs, such as Entrepreneurship Lecture, Entrepreneurship Student Creativity Program (PKMK), Integrated Work / Co-op Work / Co-op Program, Business Lecture (KKU), Entrepreneurial Student Program (PMW) and other entrepreneurship programs (Humas, 2018).

This study examines the impact of creativity and entrepreneurship education on student intentions at Universitas Negeri Jakarta. Creativity in this research consists of lecturer creativity, individual creativity, and creativity supported by the university. This research has two innovations. First, the influence of lecturer creativity on entrepreneurship education. Second, the impact of individual creativity on the intention of entrepreneurship. Several previous studies have been examining creativity about student entrepreneurship intentions (Biraglia, 2017; Yar Hamidi, 2008; Zampetakis \& 
Moustakis, 2011; and Nasiru, 2015). However, they do not examine the influence of lecturers' creativity on entrepreneurship education and student entrepreneurship intentions. Although Zampetakis (2011), has tested the influence of creativity of university support and individual creativity to student entrepreneur intent, this research did not test the lecturer's creativity on students' entrepreneurship intention. In fact, the creativity of lecturers as the findings of this research, very influential on individual creativity.

Some of the results of this study support the conclusions_Esmi \& Torkzadeh (2015); Heru (2012); Rauch (2015); and Ghina (2017). In this study, we found that there was an influence of lecturer on creativity on entrepreneurship education. Previous researchers have never revealed this finding. Our research also found the impact of individual creativity on the intention of entrepreneurship. This finding has not been revealed in some previous studies. Based on this discussion, we argue that the entrepreneurial education impact on the intentions of entrepreneurship. Moreover, when entrepreneurship education is supported lecture creativity, this impacts on university student's entrepreneurial intention.

\section{LITERATURE REVIEW}

Creativity has long been identified as a significant component of entrepreneurship, as entrepreneurs need to be able to recognize opportunities, generate ideas and innovate. It, therefore, comes as no surprise that creativity has been proposed as an antecedent of entrepreneurial intentions (Gorman et al., 1997). According to Hamidi et al. (2008), for instance, find that the more creative individuals are, the more likely they are to engage in entrepreneurship. Creativity can also influence the degree and type of novelty that entrepreneurs introduced to the economy, promoting innovative entrepreneurship (Koellinger, 2008).

Creativity and entrepreneurship are, hence, inextricably linked. Scholars also indicate that this link may be responsive to social and individual variations (Drennan et al., 2005; Krueger et al., 2000; Schmitt-Rodermund, 2004). The roles of the family (Drennan et al., 2005) and education (Davidsson, 1995) have been highlighted in existing studies. However, entrepreneurial intention models have primarily ignored the creativity-entrepreneurial intention link and the potential social and individual influences on this relationship.

Cognitive approaches to entrepreneurship hence emphasize a person's creativity as an important, yet understudied antecedent of entrepreneurial intention (Ward, 2004; Zampetakis et al., 2011). Previous empirical studies have highlighted the importance of the family and the university in influencing university student's creativity. Entrepreneurship course attendance has also been identified as a factor that is likely to affect entrepreneurial intention. Self-reporting is often used when measuring individual creativity (Farmer et al., 2003) since creative individuals have a firm sense of self as a creative person (Shalley and Gilson, 2004). Research also indicates that a creative individual is open to new experiences and that divergent thinking leads to novel and useful ideas (Amabile, 1996).

Also, creativity researchers posit that educational environments influence university students' creativity (Amabile, 1996). Studies highlight, for instance, the effects of teacher characteristics and behavior on pupil creativity in elementary schools (Amabile, 1996). Turning their attention to universities, scholars agree that exposing students to create role models within the university context endorses students' creativity (Elzubeir and Rizk, 2001). Chambers (1977) and Zampetakis et al., 2011 argue that discouraging student ideas and being too critical about novel concepts are practices that are likely to hamper creativity amongst university students.

Based on this discussion, we argue that when creativity is supported in the university environment, this impacts on university student's creativity, which in turn influences their entrepreneurial intention. The results of our initial research found that the campus carried out several activities to build student creativity. Some of these activities are business incubators, entrepreneurial competitions, PKM, PMW, giving freedom of thought and issuing opinions, and various training to shape and develop student creativity.

Entrepreneurship education is a pedagogical program or process of education for entrepreneurial attitudes and skills. It has a relatively long history and has developed into a widespread phenomenon. Several previous studies have found that entrepreneurship education and training have a positive impact on the intentions of entrepreneurship (Botsaris \& Vamvaka, 2014; Liñán \& Chen, 2009; Bergmann, 2015; Wibowo, 2018; Gird \& Bagraim, 2008; Karimi et al., 2016, and Oosterbeek et al., 2010). Entrepreneurship education conducted at the university strongly supports the emergence of student creative ideas in addition to strengthening the intention of students to become entrepreneurs.

Entrepreneurship education equips students with the additional knowledge, attributes, and capabilities required to apply these abilities in the context of setting up a new venture or business (QAA, 2012). Moreover, entrepreneurship education aims to produce graduates who are capable of identifying opportunities and developing ventures, through setting up a growing business or developing part of an existing venture. It focuses on encouraging students to apply for various skills and attributes, including new or existing businesses, charities, non-governmental organizations, the public sector, and social enterprises.

According to Soutaris et al. (2007), entrepreneurship education, especially in tertiary education, can be divided into four. First, "Entrepreneurial Awareness Education" is an education that aims to increase knowledge about entrepreneurship and influence attitudes that will generate interest. Second, education which aims to encourage someone to be able to set up a 
business (Education for Start-Up). This program is intended for people who have business ideas and need solutions to answer questions about how to become self-employed. The third category is "Education for Entrepreneurial Dynamism," which is education given to people who have run a business but want to improve their business behavior after going through the initial phase of business establishment. Fourth, continuing education for entrepreneurs (Continuing Education for Entrepreneurs) describes an all-time learning program intended for experienced entrepreneurs (Soutaris et al. 2007; Purwana, 2017).

Utilization of resources means entrepreneurial education is beneficial for individuals to obtain funds through information transfer; For example, individuals can build relationships with peers while taking entrepreneurship courses. Relationships or networks can provide prospective entrepreneurs with various information related to necessary resources (Jack, 2002). Besides, individuals may also get comments or suggestions regarding their entrepreneurial activities while attending the course. Motivation from classmates and teachers is a resource for individuals getting help and support for their entrepreneurial activities.

Although there is a significant increase in the number of courses and programs on entrepreneurial education, it has not been sufficiently integrated into the curriculum from high school to college. Also, entrepreneurial education is more often applied in business schools than in public schools (Altan, 2015). Moreover, entrepreneurial education that provides much practice allows students to gain knowledge as well as skills. In other words, effective entrepreneurship education not only allows students to have experience but also put it into practice. Such an educational model not only arouses students' interest in entrepreneurship but also practices it. The more opportunities students have for transferring knowledge into the experience; they will gain better capabilities as well (Wu \& Wu, 2008: Piperopoulos \& Dimov, 2015; Sánchez 2013; Shinnar \& Powell, 2014; and Karimi \& Mulder, 2014).

Krueger \& Carsrud (2000) and Bae \& Fiet (2014) conclusion that entrepreneurial intentions are one's desire to own one's own business or to start a business. Historically, intentions have been used to describe a self-prediction to engage in a behavior (Ajzen, 1991). That is, once the formation of intentions occurs, actual behavior is expected. Social-psychological studies assume that intention is the single best predictor of actual behavior (Karimi \& Mulder, 2014).

An understanding of entrepreneurship education-entrepreneurial intentions relationship requires an understanding of business education because it could be a more effective driver of entrepreneurial intentions. Entrepreneurship education is assumed to enhance an "awareness of entrepreneurship as an alternative career path to employment" (Karimi \& Mulder, 2014), whereas business education assists students to work at established companies (Sánchez 2013). It is reasonable that entrepreneurship education is more strongly related to entrepreneurial intentions than business education because the former is better adapted for the development of entrepreneurial skills and knowledge.

Moreover, several researchers managed to show significant impact on entrepreneurial education on the intentions of entrepreneurship. Such as Mahendra \& Hermawan (2017) who researched Malang, Indonesia against students. This research proves that there is a significant impact of entrepreneurial education on the intention of entrepreneurship. These results complement the previous findings made by QAA (2012), Fayolle \& Gailly (2015), Purwana \& Suhud (2017), Piperopoulos \& Dimov (2015), Sánchez (2013), Shinnar \& Powell (2014), Karimi \& Mulder, 2014, and Wibowo (2018).

Some studies also show a significant impact of lecture creativity along with entrepreneurship education on the entrepreneurial intention of vocational students (Piperopoulos \& Dimov, 2015; Zhao, Seibert, and Hills, 2005, and Purwana \& Suhud, 2017).

Several previous studies have found factors that stimulate student entrepreneurship intent, including entrepreneurship education, perceived barrier, perceived support, motivation, attitude, subjective norm, social norm, perceived behavioral control, and self-efficacy (Fayolle \& Gailly, 2015; Biraglia, 2017; Yar Hamidi, 2008). In the Indonesian setting, several researchers found essential factors and influenced students' entrepreneurial intentions, including entrepreneurial personality, entrepreneurship education, entrepreneurial knowledge, and the environment involving students (Wibowo, 2018; Mahendra \& Hermawan, 2017, and Purwana \& Suhud, 2017).

The authors posit the following hypotheses and develop the research model (Figure 1);

$\mathrm{H}_{1}=$ there is impact creativity supported in the university on lectures' creativity

$\mathrm{H}_{2}=$ there is impacted creativity supported in the university on entrepreneurial education

$\mathrm{H}_{3}=$ there is impact creativity supported in the university on individual creativity

$\mathrm{H}_{4}=$ there is impact creativity supported in the university on entrepreneurial intention

$\mathrm{H}_{5}=$ there is impact lectures' creativity on individual creativity

$\mathrm{H}_{6}=$ there is impact lectures' creativity on entrepreneurial education

$\mathrm{H}_{7}=$ there is impact lectures' creativity on entrepreneurial intention

$\mathrm{H}_{8}=$ there is impact entrepreneurial education on entrepreneurial intention 
$\mathrm{H}_{9}=$ there is impact individual creativity on entrepreneurial intention

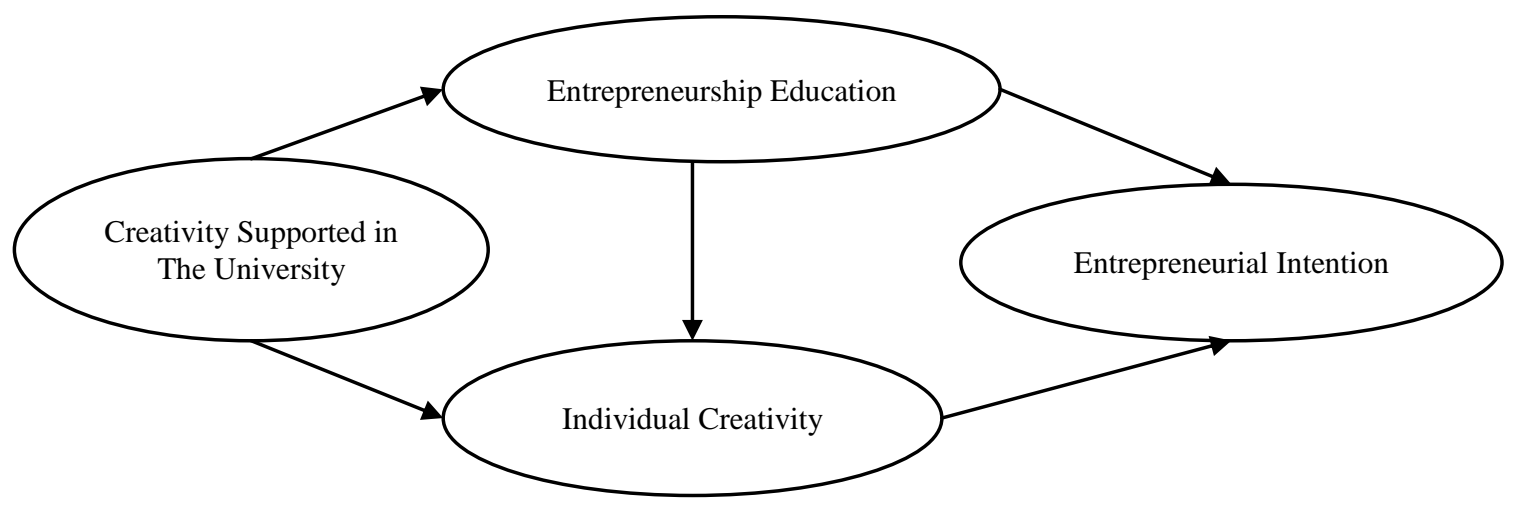

Figure 1: The Conceptual Framework

\section{METHOD AND MATERIAL}

This study, we applied quantitative research which conducting in two-phase First, we perform exploratory factor analysis test, and the second phase, we confirmatory factor analysis using AMOS version 18. The questionnaire collected data. Participants of this research are from the students of Universitas Negeri Jakarta who have attended entrepreneurship education and other supporting activities such as Entrepreneurship Lecture, Entrepreneurship Student Creativity Program (PKMK), Integrated Work/Co-op Work/Co-op Program, Business Lecture (KKU), Entrepreneurial Student Program (PMW) and other entrepreneurship programs. A total of 700 respondents, Faculty of Economics, Faculty of Social Sciences, Faculty of Mathematics, Faculty of Languages and Literature, Faculty of Engineering and Faculty of Education. The following table outlines the profile of respondents from our study.

Table 1: Profile of Respondents

\begin{tabular}{lll}
\hline Faculty & Number of Respondents & Percentage \\
\hline Faculty of Economics & 124 & 17.7 \\
Faculty of Social Sciences & 114 & 16.29 \\
Faculty of Mathematics & 115 & 16.43 \\
Faculty of Languages and Literature & 115 & 16.43 \\
Faculty of Engineering & 110 & 15.71 \\
Faculty of Education & 122 & 17.43 \\
Total & 700 & 100 \\
\hline
\end{tabular}

Furthermore, of the total participants, male 330 students (47.14 percent) and female 370 students (52.86 percent).

In this paper, we adopted seven indicators from Denanyoh et al. (2015) and Opoku-Antwi et al. (2012) to measure entrepreneurial education. Six indicators from Roblendo et al. (2015) and Liñán (2009) were we adapted to measure entrepreneurial intention. Individual creativity was therefore assessed using eight items adapted from Amabile (1996); Farmer et al. (2003), Alenizi, M. (2008, and Shalley and Gilson (2004). Furthermore, creativity supported in the university was assessed using four items adapted from Amabile et al., 1996 and Leonidas A. Zampetakis (2011). To collect data, we used seven-point Likert's scale was applied for each variable from 1 for extremely disagree to 7 for extremely agree.

\section{FINDING}

In this paper, we do two stages of analyzing the data. The first stage, we perform exploratory factor analysis test using SPSS version 18. This analysis is a way to validate the data as well as to explore dimensions and retain firmed indicators (Allen \& Bennett, 2010), and followed by a reliability test. According to Hair Jr., Black, Babin, Anderson, \& Tatham, (2006), a construct should be reliable if it has a Cronbach's alpha $(\alpha)$ score of 0.6 and higher.

The second stage, we do confirmatory factor analysis using AMOS version 18. According to Schermelleh \& Müller (2003), the tested model should have some criteria and cut-off values, that is $p$ (probability) of $>0.5$ to achieve a fitted model. The value of CMIN / DF of < 2 (Tabachnick \& Fidell, 2007), CFI of > 0.95 (Hu \& Bentler, 1995), and RMSEA of $\leq 0.05 \mathrm{Hu} \&$ Bentler, (1995).

\section{Exploratory Factor Analysis}

Based on the exploratory factor analysis result as seen in the table below, in total there are 27 factors including entrepreneurship education (6), entrepreneurial intention (6), lectures' creativity (6), individual creativity (6) and creativity 
supported in the university (3). All factors have a Cronbach's alpha ranging from 0.639 to 0.805 , and they are considered reliable to be included in further analysis (Table 2).

Table 2: Result of Exploratory Factor Analysis

\begin{tabular}{llc}
\hline & Dimension and indicators & Factor Loadings \\
\hline 1 & Entrepreneurship Education (EE) & $\alpha=0.736$ \\
Ee2 & My university provides the necessary knowledge about entrepreneurship & 0.732 \\
Ee4 & My university makes me develop my skills & 0.685 \\
Ee3 & My university develops my entrepreneurial skills and abilities & 0.681 \\
Ee6 & Entrepreneurship can be developed through education & 0.665 \\
Ee1 & Education at university encourages me to develop creative ideas for & being an \\
& entrepreneur & 0.631 \\
Ee5 & My university teaches students about entrepreneurship and starting a business & 0.612 \\
2 & Entrepreneurship Intention (EI) & $\alpha=0.758$ \\
Ei3 & I have serious doubts about ever starting my own business & 0.765 \\
Ei5 & My professional goal is to be an entrepreneur & 0.719 \\
Ei2 & I will make every effort to start and run my own business & 0.693 \\
Ei1 & I am ready to do anything to be an entrepreneur & 0.687 \\
Ei4 & I am determined to create a business venture in the future & 0.664 \\
Ei6 & I have a very low intention of ever starting a business & 0.608 \\
3 & Individual Creativity (IC) & $\alpha=0.701$ \\
Ic4 & I typically create new ideas by combining existing ideas & 0.802 \\
Ic3 & I can quickly think a lot of different and useful ideas & 0.740 \\
Ic5 & I often use the technique of brainstorming to come up with new the idea & 0.733 \\
Ic6 & I do a lot of experimentation (trial and error) to come up with a new workable idea & 0.652 \\
Ic8 & I intentionally engage in unpopular ideas & 0.874 \\
Ic7 & I make random attempts to solve a difficult problem & 0.788 \\
4 & Creativity Supported in the university (UC) & $\alpha=0.639$ \\
Uc1 & In my university, you learn that there is more than one solution to a problem. & 0.846 \\
Uc2 & In my university, you learn to examine old problems in new ways & 0.821 \\
Uc3 & In my university, the faculty encourages students to produce new and useful ideas.' & 0.687 \\
\hline
\end{tabular}

\section{Hypotheses Testing}

According to the calculation of SEM for examining the theoretical framework, a fitted model was obtained with a probability score $(p)$ of 0.303, CMIN/DF score of 1.088, CFI score of 0.997, RMSEA score of 0.011 and FMIN score of 0.087. As presented in the table below, $\mathrm{H}_{1}, \mathrm{H}_{2}, \mathrm{H}_{3}, \mathrm{H}_{5}, \mathrm{H}_{6}, \mathrm{H}_{7}$, and $\mathrm{H}_{8}$ are significant with C.R. score of 5.147, 2.871, 2.038, 3.291, 7.345, 2.444 and 6.005 respectively. These scores indicate significance (Hair Jr. et al., 2006). $\mathrm{H}_{4}$ is significant with $\mathrm{b}=0.687$ (Hair Jr. et al., 2006). In contrast, $\mathrm{H}_{4}$ and $\mathrm{H}_{9}$ are insignificant with a C.R. score of -0.302 and 0.242.

\section{DISCUSSION}

The results of this study answered nine hypotheses. The first hypothesis $\left(\mathrm{H}_{1}\right)$, there is a direct positive impact creativity supported in the university on lectures' creativity. The results of the study found that $\mathrm{H}_{1}$ is significant with a C.R. score of 5.147. This means that the creativity supported in the university hard directly impact on lectures' creativity. This study supports the findings of Yar Hamidi et al., (2008), that support from the university will improve the lecturer's creativity. With the support of the university, lecturers can continue to update their knowledge, follow various training and education, attend workshops, seminars and workshops that support their creativity. Moreover, this study means that lectures' creativity can explain creativity supported in the university.

The second hypothesis, there is a direct positive impact creativity supported in the university on entrepreneurial education. The results of this research indicate that creativity supported in the university has a direct positive impact on entrepreneurial education $($ C.R. $=2.871)$. This means that entrepreneurial education can explain creativity supported in the university. Thus the second hypothesis is accepted. The results are in line with the findings Zampetakis et al. (2011) and Amabile (1996). Furthermore, Zampetakis et al. (2011) argue that with support from the university, entrepreneurial education can be effective. Moreover, the results of this study support the findings of Elzubeir and Rizk, (2001) and Wibowo, (2018) that educational environments or creativity supported in the university impact on individual creativity.

The third hypotheses, there is a direct positive impact creativity supported in the university on individual creativity. The results found that there is direct positive impact creativity supported in the university on individual creativity $(\mathrm{C} . \mathrm{R}$. = 2.038). Thus the third hypothesis is accepted. This means that individual creativity can explain creativity supported in the university. The results are in line with the findings Amabile (1996) and Zampetakis et al. (2011) and Furthermore, Zampetakis et al. (2011) argue that with support from the university, entrepreneurial education can be useful. Moreover, 
the results of this study support the findings of Amabile (1996) that educational environments or creativity supported in the university impact on individual creativity.

Table 3: Result Summary of Hypotheses testing

\begin{tabular}{|c|c|c|c|c|c|c|}
\hline $\begin{array}{l}\text { Independent } \\
\text { Variable }\end{array}$ & & $\begin{array}{l}\text { Dependent } \\
\text { Variable }\end{array}$ & C.R. & $P$ & $S d . T E$ & Result \\
\hline $\mathrm{H}_{1} \quad \mathrm{UC}$ & $\rightarrow$ & LC & 5.147 & $* * *$ & 0.311 & Accepted \\
\hline $\mathrm{H}_{2} \mathrm{UC}$ & $\rightarrow$ & $\mathrm{EE}$ & 2.871 & 0.004 & 0.359 & Accepted \\
\hline $\mathrm{H}_{3} \mathrm{UC}$ & $\rightarrow$ & IC & 2.038 & 0.042 & 0.326 & Accepted \\
\hline $\mathrm{H}_{4} \mathrm{UC}$ & $\rightarrow$ & EI & -0.302 & 0.762 & 0.350 & unaccepted \\
\hline $\mathrm{H}_{5} \mathrm{LC}$ & $\rightarrow$ & IC & 3.291 & 0.001 & 0.269 & Accepted \\
\hline $\mathrm{H}_{6} \mathrm{LC}$ & $\rightarrow$ & $\mathrm{EE}$ & 7.345 & $* * *$ & 0.607 & Accepted \\
\hline $\mathrm{H}_{7} \mathrm{LC}$ & $\rightarrow$ & EI & 2.444 & 0.015 & 0.742 & Accepted \\
\hline $\mathrm{H}_{8} \mathrm{EE}$ & $\rightarrow$ & EI & 6.005 & $* * *$ & 0.796 & Accepted \\
\hline $\mathrm{H}_{9} \mathrm{IC}$ & $\rightarrow$ & EI & 0.242 & 0.809 & 0.18 & unaccepted \\
\hline
\end{tabular}

$\mathrm{H}=$ Hypotheses; Sd.TE $=$ Standardized Total Effect; Creativity supported in the university=UC, Lectures' Creativity=LC, Entrepreneurial Education=EE, Entrepreneurial Intention=EI, and Individual Creativity=IC

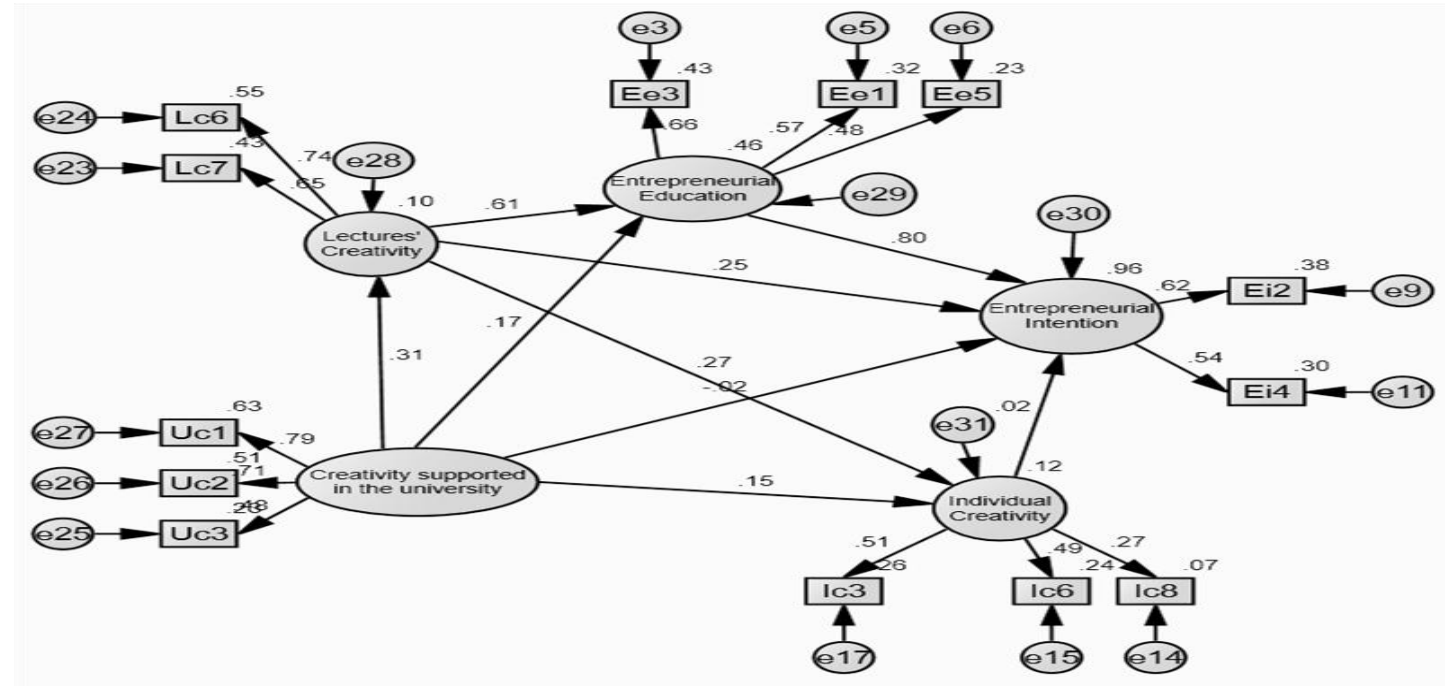

Figure 2: The Result of Structural Equation Model

The fourth hypotheses, there is the direct positive impact of creativity supported in the university on entrepreneurial intention. The results of this research indicate that creativity supported in the university has no direct effect on entrepreneurial intention (C.R. = -0.302). Thus, the fourth hypothesis is unaccepted. The results of this study show that contradict with the findings of, Hamidi et al. (2008) and Zampetakis et al. (2011), that should the creativity be supported in the university impact on entrepreneurial intention. Differences of research results with literature review caused the students have not realized the role of universities in growing the intention of becoming an entrepreneur. Thus, the university should improve socialization and the real role of support for the presence of a conducive climate that encourages entrepreneurship entrepreneur interest. This is in line with the opinion of Zampetakis et al. (2011) that the role of the university should be more significant so that more and more students are interested in entrepreneurship.

The fifth hypotheses, there is direct positive impact lectures' creativity on individual creativity. The results found that there is direct positive impact lectures' creativity on individual creativity (C.R. = 2.038). Thus the fifth hypotheses are accepted. This means that individual creativity can explain lectures' creativity. The results are in line with the findings Zampetakis et al. (2011), Alenizi, M. (2008), Dobbins, K. (2009) and Rasmi (2012) that the impact of lectures' creativity, will inspire and motivate students to be creative as well.

The sixth hypotheses, there is direct positive impact lectures' creativity on entrepreneurial education. The results found that there is direct positive impact lectures' creativity on entrepreneurial education (C.R.= 7.345). Thus, the sixth hypothesis is accepted. The results of this study support the findings of Opoku-Antwi (2012); Alenizi, M. (2008); Zhao, Seibert, and Hills (2005), and Wibowo (2018), that the lectures' creativity impact on entrepreneurial education.

The seventh hypotheses, there is direct positive impact lectures' creativity on entrepreneurial intention. The results found that there is direct positive impact lectures' creativity on entrepreneurial intention $($ C.R. $=2.444)$. Thus, the seventh 
hypothesis is accepted. The results of this study support the findings Dobbins, K. (2009), Opoku-Antwi (2012), Zhao, Seibert, and Hills (2005), and Wibowo (2018), that the lectures' creativity impact on entrepreneurial intention.

The eighth hypothesis, there is a direct positive impact on entrepreneurial education on entrepreneurial intention. The results found that entrepreneurial education impact on entrepreneurial intention (C.R. =6.005). Thus the eighth hypothesis is accepted. The results of this study support the findings of Opoku-Antwi (2012); Susetyo and Lestari (2014); Zhao, Seibert, and Hills (2005), Purwana \& Suhud (2017), and Wibowo (2018) that entrepreneurial education on entrepreneurial intention.

The ninth hypothesis, there is a direct positive impact on individual creativity on entrepreneurial intention. The results of this research indicate that individual creativity has no direct positive impact on entrepreneurial intention $($ C.R. $=0.242)$. Thus, the ninth hypothesis is unaccepted. The results of this study show that contradict with the findings of Hamidi et al. (2008) and Zampetakis et al. (2011) that should the individual creativity impact on entrepreneurial intention. Differences of research results with literature review caused the students cannot distinguish individual creativity with motivation and selfefficacy. Future research should provide a firm understanding and limitation regarding individual creativity so that students can understand it. These findings are in line with the opinion of Zampetakis et al. (2011) that it is difficult to differentiate and identify individual creativity with motivation and self-efficacy.

\section{CONCLUSION}

This study examines the impact of creativity and entrepreneurship education on student intentions at Universitas Negeri Jakarta. This study carried out the findings: First, there is impact creativity supported in the university on lectures' creativity. Second, there is impact creativity supported in the university on entrepreneurial education. Third, there is impact creativity supported in the university on individual creativity. Fourth, creativity supported in the university has no direct effect on entrepreneurial intention. Fifth, there is impact lectures' creativity on individual creativity. Sixth, there is impact lectures' creativity on entrepreneurial education. Seventh, there is impact lectures' creativity on entrepreneurial intention. Eighth, there is an impact on entrepreneurial education on entrepreneurial intention, and ninth individual creativity has no direct positive impact on entrepreneurial intention. Thus, the ninth hypothesis is unaccepted.

Based on the conclusions suggested: First, the university should improve socialization and the real role of support for the presence of a conducive climate that encourages entrepreneurship entrepreneur interest. Moreover, universities should further enhance activities that support individual creativity such as Entrepreneurship Lecture, Entrepreneurship Student Creativity Program (PKMK), Integrated Work / Co-op Work/Co-op Program, Business Lecture (KKU), Entrepreneurial Student Program (PMW) and other entrepreneurship programs. Second, the university must provide facilitating and developing business incubation as laboratories, internet networks, books, and other literature to support improving the individual creativity and quality of entrepreneurship learning.

Although our study finds some light on the impact of creativity on university students' entrepreneurial intention, it has several limitations that further research can seek to address. First, our study was limited to a sample of Universitas Negeri Jakarta students in Indonesia. To extend the generalizability of our results, we encourage scholars in this area to examine our proposed model with students in other disciplines and across different universities, regions, and countries. Future research could also look into the influence of creativity training programs on entrepreneurial intentions. Finally, our study highlighted interesting insights into the role that the teachers' creativity, entrepreneurial education, and entrepreneurship course attendance may play in mobilizing the creativity-entrepreneurial intention link in university students. Our understanding of why and how these factors interact could be further explored. Further research can delve deeper into understanding these relationships by employing a qualitative approach or mix methods.

\section{REFERENCES}

1. Ács, Z., Szerb, L., \& Autio, E. (2018). Global Entrepreneurship and Development Index 2018. In Global Entrepreneurship and Development Index 2018. https://doi.org/10.4337/9781782540427.

2. Ajzen, I. (1991). The theory of planned behavior. Organizational Behavior and Human Decision Processes, 50(2), 179-211. https://doi.org/10.1016/0749-5978(91)90020-t

3. Alenizi, M. (2008). Assessment of Creativity in Education, 19. https://doi.org/10.1017/CBO9780511763205.005

4. Allen, P.J., \& Bennett, K. (2010). PASW statistics by SPSS: A practical guide. Version 18.0. Cengage Learning.

5. Altan, M. Z. (2015). Entrepreneurial teachers teaching entrepreneurial. Journal for Educators, Teachers and Trainers, 6(2), 35-50. Retrieved from http://jett.labosfor.com/index.php/jett/article/view/205/200.

6. Amabile, T. M. (1996). Creativity in context: Update to “The Social Psychology of Creativity." Boulder, CO, US: Westview Press.

7. Ananda, K. (2009). Creative Teaching And Its Assessment. UNESCO-APEID International Conference, (March 2009), 1-15.

8. Ayob, Afida, Hussain, A. \& A. R. (2013). A Review of Research on Creative Teachers in Higher Education. International Education Studies, 6(6), 61-65. https://doi.org/10.5539/ies.v6n6p8

9. Bae, T. J., Qian, S., Miao, C., \& Fiet, J. O. (2014). The Relationship Between Entrepreneurship Education and Entrepreneurial Intentions: A Meta-Analytic Review. Entrepreneurship: Theory and Practice, 38(2), $217-254$. 
https://doi.org/10.1111/etap.12095.

10. Bergmann O., Zdunek S., Felker A., Salehpour M., Alkass K., Bernard S., et al. (2015). Dynamics of cell generation and turnover in the human heart. Cell 161 1566-1575. https://doi.org/10.1016/j.cell.2015.05.026.

11. Biraglia, A., \& Kadile, V. (2017). The Role of Entrepreneurial Passion and Creativity in Developing Entrepreneurial Intentions: Insights from American Homebrewers. Journal of Small Business Management, 55(1). https://doi.org/10.1111/jsbm.12242

12. Botsaris, C., \& Vamvaka, V. (2014). Attitude Toward Entrepreneurship : Structure, Prediction from Behavioral Beliefs, and Relation to Entrepreneurial Intention. https://doi.org/10.1007/s13132-014-0227-2

13. Cayirdag, N. (2017). Creativity Fostering Teaching: Impact of Creative Self-efficacy and Teacher Efficacy. Educational Sciences: Theory \& Practice, 17(6), 1959-1975. https://doi.org/10.12738/estp.2017.6.0437.

14. Chambers, J. A. (1977). College teachers: their effect on creativity of students'. Journal of Educational Psychology. Vol 65, pp 326-334. https://doi.org/10.1037/h0035632

15. Davidsson, P. (2015). Entrepreneurial opportunities and the entrepreneurship nexus: A re-conceptualization. Journal of Business Venturing, 30(5), 674-695. https://doi.org/10.1016/j.jbusvent.2015.01.002

16. Denanyoh, R., Adjei, K., \& Nyemekye, G. E. (2015). Factors That Impact on Entrepreneurial Intention of Tertiary Students in Ghana. International Journal of Business and Social Research, 05(03), 19-29.

17. Dobbins, K. (2009). Teacher creativity within the current education system: a case study of the perceptions of primary teachers. Education 3-13, 37(2), 95-104. https://doi.org/10.1080/03004270802012632.

18. Drennan, J., Kennedy, J. and Renfrow, P. (2005), "Impact of childhood experiences on the development of entrepreneurial intentions", International Journal of Entrepreneurship \& Innovation, Vol. 6 No. 4, pp. 231-8. https://doi.org/10.5367/000000005775179801

19. D Susetyo, SL Prasilowati. (2014). Developing entrepreneurial intention model of university students: an empirical study on university students in Semarang Indonesia. International Journal of Engineering and Management Sciences 5 (3), 184-196.

20. Elzubeir MA, Rizk DE. (2001). Identifying characteristics that students, interns and residents look for in their role models. Med Educ. 35(3):272-7. https://doi.org/10.1046/j.1365-2923.2001.00870.x

21. Esmi, K., Marzoughi, R., \& Torkzadeh, J. (2015). Teaching learning methods of an entrepreneurship curriculum. Journal of Advances in Medical Education \& Professionalism, 3(4), 172-177. Retrieved from http://www.ncbi.nlm.nih.gov/pubmed/26457314

22. Estrin, S., Meyer, K. E., \& Bytchkova, M. (2009). Entrepreneurship in Transition Economies. The Oxford Handbook of Entrepreneurship, (24), 1-47. https://doi.org/10.1093/oxfordhb/9780199546992.003.0027.

23. Farmer, Steven \& Tierney, Pamela \& Kung-Mcintyre, Kate. (2003). Employee Creativity in Taiwan: An Application of Role Identity Theory. Academy of Management Journal. $46.618-630$. https://doi.org/10.2307/30040653.

24. Fayolle, A., \& Gailly, B. (2015). The impact of entrepreneurship education on entrepreneurial attitudes and intention: Hysteresis and persistence. Journal of Small Business Management, 53(1), 75-93. https://doi.org/10.1111/jsbm.12065

25. Fayolle, A., Liñán, F., \& Moriano, J. A. (2014). Beyond entrepreneurial intentions: values and motivations in entrepreneurship. International Entrepreneurship and Management Journal, 10(4). https://doi.org/10.1007/s11365-014-0306-7

26. George Lord, O.-A., Amofah, K., Kofi Nyamaah, K., \& Abubakari, Y. (2012). Entrepreneurial intention among senior high school students in the Sunyani Municipality. International Review of Management and Marketing, 2(4), 210-219.

27. Ghina, A., Simatupang, T. M., \& Gustomo, A. (2017). The relevancy of graduates' competencies to the effectiveness of entrepreneurship education: A case study at SBM ITB-Indonesia. Journal of Entrepreneurship Education, 20(1), 1-24.

28. Hair Jr., J. F., Black, W. C., Babin, B. J., Anderson, R. E., \& Tatham, R. L. (2006). Multivariate data analysis (6th ed.). New Jersey: Prentice-Hall, Inc.

29. Heru Priyanto, S. (2012). Entrepreneurial and vocational learning in entrepreneurship education: Indonesian Non formal education perspective. Basic Research Journal of Business Management and Accounts, 1(2), 30-36. Retrieved from http//www.basicresearchjournals.org

30. Hu, L.-t., \& Bentler, P. M. (1995). Structural equation modeling. Concepts, issues, and applications. (Evaluating model fit. In R. H. Hoyle (Ed.), Ed.). London: Sage.

31. Hu, L.-t., \& Bentler, P. M. (1999). Cutoff criteria for fit indexes in covariance structure analysis: Conventional criteria versus new alternatives. Structural Equation Modeling: A Multidisciplinary Journal, 6(1), 1-55. https://doi.org/10.1080/10705519909540118

32. Humas. (2018). Program Mahasiswa Wirausaha (PMW) Universitas Negeri Jakarta. Retrieved October 6, 2018, from http://unj.ac.id/pr3/?page_id=600.

33. Jack, S.L. \& Anderson, A.R. (2002). The effects of embeddedness on the entrepreneurial process. Journal of Business Venturing, 17, 467-487. https://doi.org/10.1016/S0883-9026(01)00076-3

34. Jeffrey, B., \& Craft, A. (2004). Teaching creatively and teaching for creativity: Distinctions and relationships. 
Educational Studies, 30(1), 77-87. https://doi.org/10.1080/0305569032000159750

35. Karimi, S., Biemans, H. J. A., Lans, T., Chizari, M., \& Mulder, M. (2016). The Impact of Entrepreneurship Education: A Study of Iranian Students' Entrepreneurial Intentions and Opportunity Identification. Journal of Small Business Management, 54(1), 187-209. https://doi.org/10.1111/jsbm.12137.

36. Karimi, S., J.A. Biemans, H., Lans, T., Chizari, M., \& Mulder, M. (2014). Effects of role models and gender on students' entrepreneurial intentions. European Journal of Training and Development, 38(8), 694-727. https://doi.org/10.1108/EJTD-03-2013-0036.

37. Krueger, N., Reilly, M. and Casrund, A. (2000), "Competing models of entrepreneurial intentions", Journal of Business Venturing, Vol. 15 Nos 5/6, pp. 411-32. https://doi.org/10.1016/S0883-9026(98)00033-0

38. Lee, L., Wong, P. K., Foo, M. Der, \& Leung, A. (2011). Entrepreneurial intentions: The influence of organizational and individual factors. Journal of Business Venturing, 26(1), $124-136$. https://doi.org/10.1016/j.jbusvent.2009.04.003.

39. Lin, Y.-S. (2011). Fostering Creativity through Education - A Conceptual Framework of Creative Pedagogy. Creative Education, 02(03), 149-155. https://doi.org/10.4236/ce.2011.23021.

40. Liñán, F., \& Chen, Y. (2009). Development and Cross-Cultural Application of a Specific Instrument to Measure Entrepreneurial Intentions. ENTREPRENEURSHIP THEORY and PRACTICE, 593-617. https://doi.org/10.1111/j.1540-6520.2009.00318.x

41. Löbler, H. (2006). Learning entrepreneurship from a constructivist perspective. Technology Analysis and Strategic Management, 18(1), 19-38. https://doi.org/10.1080/09537320500520460.

42. Lord Opoku-Antwi, George \& Amofah, Kwaku \& Nyamaah-Koffuor, Kofi \& Yakubu, Abubakari. (2012). Entrepreneurial Intention Among Senior High School Students in the Sunyani Municipality. International Review of Management and Marketing. 2.

43. Mahendra, A. M., Djatmika, E. T., \& Hermawan, A. (2017). The Effect of Entrepreneurship Education on Entrepreneurial Intention Mediated by Motivation and Attitude among Management Students, State University of Malang, Indonesia. International Education Studies, 10(9), 61. https://doi.org/10.5539/ies.v10n9p61

44. Mason, C., \& Arshed, N. (2013). Teaching Entrepreneurship to University Students through Experiential Learning: A Case Study. Industry and Higher Education, 27(6), 449-463. https://doi.org/10.5367/ihe.2013.0180

45. Nasiru, A., Keat, O. Y., \& Bhatti, M. A. (2015). Influence of Perceived University Support, Perceived Effective Entrepreneurship Education, Perceived Creativity Disposition, Entrepreneurial Passion for Inventing and Founding on Entrepreneurial Intention. Mediterranean Journal of Social Sciences, (June). https://doi.org/10.5901/mjss.2015.v6n3p88

46. Obschonka, M., Silbereisen, R. K., \& Schmitt-Rodermund, E. (2010). Entrepreneurial intention as developmental outcome. Journal of Vocational Behavior, 77(1), 63-72. https://doi.org/10.1016/j.jvb.2010.02.008

47. Oosterbeek, H., van Praag, M., \& Ijsselstein, A. (2010). The impact of entrepreneurship education on entrepreneurship skills and motivation. European Economic Review, 54(3), $442-454$. https://doi.org/10.1016/j.euroecorev.2009.08.002

48. Padilla-Meléndez, A., Fernández-Gámez, M. A., \& Molina-Gómez, J. (2014). Feeling the risks: effects of the development of emotional competences with outdoor training on the entrepreneurial intent of university students. International Entrepreneurship and Management Journal, 10(4), 861-884. https://doi.org/10.1007/s11365-0140310-y

49. Peltonen, K. (2015). How can teachers' entrepreneurial competences be developed? A collaborative learning perspective. Education + Training, 57(5). https://doi.org/10.1108/ET-03-2014-0033

50. Peng, Z., Lu, G., \& Kang, H. (2012). Entrepreneurial Intentions and Its Influencing Factors: A Survey of the University Students in Xi'an China. Creative Education, 03(08), 95-100. https://doi.org/10.4236/ce.2012.38B021.

51. Philipp Koellinger.(2008). The relationship between technology, innovation, and firm performance--Empirical evidence from e-business in Europe. Research Policy, 37, (8), 13171328.https://doi.org/10.1016/j.respol.2008.04.024

52. Pihkala, T., Ruskovaara, E., Seikkula-Leino, J., \& Rytkölä, T. (2011). Entrepreneurship Education - What is really happening in class rooms? Paper Presented at YKTT.

53. Piperopoulos, P., \& Dimov, D. (2015). Burst Bubbles or Build Steam? Entrepreneurship Education, Entrepreneurial Self-Efficacy, and Entrepreneurial Intentions. Journal of Small Business Management, 53(4), 970-985. https://doi.org/10.1111/jsbm.12116

54. Pishghadam, Reza.,Ghorbani, Nejad Tahereh., \& Shayesteh, S. (2012). Creativity and its Relationship with Teacher Success Criatividade, 3(2), 204-216. https://doi.org/10.4304/jltr.2.4.909-917

55. Plucker, J. A., Waitman, G. R., \& Hartley, K. A. (2011). Education and Creativity. Encyclopedia of Creativity, (February 2013), 435-440. https://doi.org/10.1016/B978-0-12-375038-9.00086-8

56. Purwana, D., \& Suhud, U. (2017). Entrepreneurship Education and Taking / Receiving \& Giving ( TRG ) Motivationson Entrepreneurial Intention : Do Vocational School Students Need an Entrepreneurial Motivator?, (2016).

57. Puspayoga. (2017). Target Ratio Kewirausahaan 2017 Capai 4. Humas Kementerian Koperasi Dan UKM. Retrieved from http://www.depkop.go.id/content/read/menteri-puspayoga-target-ratio-kewirausahaan-2017-capai- 
4/

58. QAA. (2012). Enterprise and entrepreneurship education: Guidance for UK higher education providers. UK: The Quality Assurance Agency for Higher Education. https://doi.org/ISBN: 9781849796927

59. Rasmi. (2012). Fostering Creativity: A Four Elemental Model of Creative Pedagogy. Journal of Education and Practice, 3(12), 190-201.

60. Rauch, A. (2015). Putting entrepreneurship education where the intention to act lies An investigation into the Impact of ... Putting Entrepreneurship Education Where the Intention to Act Lies : An Investigation Into the Impact of Entrepreneurship Education on Entrepreneuri. Academy of Management Learning \& Education, 14(July), 187-204. https://doi.org/10.5465/amle.2012.0293

61. Robledo, J. L. R., Arán, M. V., Sanchez, V. M., \& Molina, M. Á. R. (2015). The moderating role of gender on entrepreneurial intentions:InA TPB perspective. Intangible Capital, 11(1), 92-117. https://doi.org/10.3926/ic.557

62. Rowley, Jennifer \& Baregheh, Anahita \& Sambrook, Sally. (2011). Towards an innovation-type mapping tool. Management Decision. 49. 73-86. https://doi.org/10.1108/00251741111094446.

63. Sánchez, J. C. (2013). The impact of an entrepreneurship education program on entrepreneurial competencies and intention. Journal of Small Business Management, 51(3), 447-465. https://doi.org/10.1111/jsbm.12025

64. Schermelleh-Engel, K., Moosbrugger, H., \& Müller, H. (2003). Evaluating the fit of structural equation models: Tests of significance and descriptive goodness-of-fit measures. Methods of Psychological Research Online, 8(2), 23-74.

65. Schmitt-Rodermund, Eva. (2004). Pathways to Successful Entrepreneurship: Parenting, Personality, Early Entrepreneurial Competence, and Interests. Journal of Vocational Behavior. 65. 498-518. https://doi.org/10.1016/j.jvb.2003.10.007.

66. Shane, Scott \& Venkataraman, Sankaran. (2013). The Promise of Entrepreneurship As A Field of Study. The Academy of Management Review. 25. https://doi.org/10.2307/259271.

67. Shalley, C. E., \& Gilson, L. L. (2004). What leaders need to know: A review of social and contextual factors that can foster or hinder creativity. The Leadership Quarterly, 15(1), 33-53. https://doi.org/10.1016/j.leaqua.2003.12.004.

68. Shinnar, R. S., Hsu, D. K., \& Powell, B. C. (2014). Self-efficacy, entrepreneurial intentions, and gender: Assessing the impact of entrepreneurship education longitudinally. International Journal of Management Education, 12(3), 561-570. https://doi.org/10.1016/j.ijme.2014.09.005.

69. Souitaris, Vangelis \& Zerbinati, Stefania \& Al-Laham, Andreas. (2007). Do Entrepreneurship Programmes Raise Entrepreneurial Intention of Science and Engineering Students? The Effect of Learning, Inspiration and Resources. Journal of Business Venturing. 22. 566-591. https://doi.org/10.1016/j.jbusvent.2006.05.002.

70. Tabachnick, B. G., \& Fidell, L. S. (2007). Using multivariate statistics (5th ed.). Boston, MA, : Allyn \& Bacon/Pearson Education.

71. TORRANCE, E. P. (1972). Can We Teach Children To Think Creatively? The Journal of Creative Behavior. https://doi.org/10.1002/j.2162-6057.1972.tb00923.x

72. Van Gelderen, M., Kautonen, T., \& Fink, M. (2015). From entrepreneurial intentions to actions: Self-control and action-related doubt, fear, and aversion. Journal of Business Venturing, 30(5), 655-673. https://doi.org/10.1016/j.jbusvent.2015.01.003

73. Walter, S. G., \& Block, J. H. (2016). Outcomes of entrepreneurship education: An institutional perspective. Journal of Business Venturing, 31(2), 216-233. https://doi.org/10.1016/j.jbusvent.2015.10.003.

74. Ward, Thomas. (2004). Cognition, Creativity, and Entrepreneurship. Journal of Business Venturing. 19. $173-188$. https://doi.org/10.1016/S0883-9026(03)00005-3.

75. Wibowo, Agus, \& Saptono, A. (2018). DOES ENTREPRENEURIAL LEADERSHIP IMPACT ON CREATIVITY AND INNOVATION OF ELEMENTARY TEACHERS? Journal of Entrepreneurship Education, 21(2), 1-9.

76. Wibowo, Agus, Saptono, A \& Suparno (2018). DOES TEACHERS' CREATIVITY IMPACT ON VOCATIONAL STUDENTS' ENTREPRENEURIAL INTENTION? Journal of Entrepreneurship Education, 21(2), 1-12.

77. Wu, S., \& Wu, L. (2008). The impact of higher education on entrepreneurial intentions of university students in China. Journal of Small Business and Enterprise Development, 15(4), $752-774$. https://doi.org/10.1108/14626000810917843

78. Yar Hamidi, D., Wennberg, K., \& Berglund, H. (2008). Creativity in entrepreneurship education. Journal of Small Business and Enterprise Development, 15(2), 304-320. https://doi.org/10.1108/14626000810871691

79. Zampetakis, L. A., Gotsi, M., Andriopoulos, C., \& Moustakis, V. (2011). Creativity and Entrepreneurial Intention in Young People. The International Journal of Entrepreneurship and Innovation, 12(3), $189-199$. https://doi.org/10.5367/ijei.2011.0037

80. Zhou, C., \& Luo, L. (2012). Group Creativity in Learning Context: Understanding in a Social-Cultural Framework and Methodology. Creative Education, 3(4), 392-399. https://doi.org/10.4236/ce.2012.34062

81. Zhao, H., Seibert, S. E., \& Hills, G. E. (2005). The Mediating Role of Self-Efficacy in the Development of Entrepreneurial Intentions. Journal of Applied Psychology, 90(6), 1265-1272. https://doi.org/10.1037/00219010.90.6.1265 